\title{
Tingkat Akseptabilitas dan Tolerabilitas Cairan Pencuci Tangan Formula World Health Organization (WHO) yang Digunakan Mahasiswa Kepaniteraan Klinik Senior di RSUD Arifin Achmad Provinsi Riau
}

\author{
Dewi Anggraini ${ }^{1}$, Insan Fitriyani ${ }^{2}$, Tuti Restuastuti ${ }^{3}$
}

\begin{abstract}
Health Care Associated Infection (HCAI) is one of the leading cause of mortality and morbidity in hospital and other health care facilitiy. Hand hygiene is the main way to reduce incidence of HCAI. World Health Organization (WHO) recommends alcohol-based handrub because it is more acceptable and tolerable than other hand hygiene products. WHO has identified formulations for the local preparation. This was a descriptive study aimed to determine the acceptability and tolerability of WHO recommended handrub formulation. The subjects of the study were 40 senior clerkships in Arifin Achmad Hospital, Riau Province, from Surgery, Obstetrics and Gynecology, and Internal Medicine Department. Each respondent was given WHO-recommended handrub formulation used for three days. On the first day, the observer distributed handrubs being tested. After 3 days of consecutive use of the product, participants completed the questionnaire and the observer evaluate the condition of participants' hands. We used WHO's questionnaire to evaluate acceptability and tolerability level. The results of this study showed that WHO-recommended handrub formulation had good acceptability for its application, colour, smell, irritation, ease of use, speed of drying, and overall evaluation but had a less rate of acceptability for its textures and drying effect. WHO-recommended handrub formulation had good tolerability.
\end{abstract}

Keywords: Acceptability, tolerability, WHO, alcohol handrub

Infeksi nosokomial atau Health Care Associated Infection (HCAI) merupakan salah satu penyebab utama kematian dan kesakitan di rumah sakit maupun fasilitas pelayanan kesehatan lainnya. ${ }^{1}$ HCAI dapat menyebabkan penyakit yang lebih berat, perpanjangan lama sakit, perpanjangan lama rawat, penambahan biaya rawat, dan kematian., ${ }^{2,3}$ Berdasarkan data Bina Program RSUD Arifin Achmad Provinsi Riau, persentase HCAI di RSUD Arifin Achmad Provinsi Riau tahun 2005 adalah sebesar 16,69\%, tahun 2006 sebesar 7,42\%, tahun 2007 sebesar 4,56\%, tahun 2009 sebesar 5,05\%. Pada tahun 2010 dan 2011 incidence rate HCAI di

\footnotetext{
1 Penulis untuk korespondensi: Bagian Mikrobiologi, Fakultas Kedokteran Universitas Riau, Alamat: Jl. Diponegoro No. 1,e-maildewianggrainiyovi@yahoo.com.

2 Mahasiswa Fakultas Kedokteran Universitas Riau

3 Bagian Ilmu Kesehatan Masyarakat Fakultas Kedokteran Universitas Riau
}

RSUD Arifin Achmad mengalami fluktuasi. Sebaran HCAI di RSUD Arifin Achmad pada tahun 2010 yaitu, infeksi saluran kemih 1,24\%, infeksi luka operasi $0,1 \%$, pneumonia $0,3 \%$, sepsis $1,95 \%$, dekubitus $0,89 \%$, dan plebitis $4,09 \%$. Sementara itu, pada tahun 2011 infeksi saluran kemih menjadi $0,05 \%$, infeksi luka operasi $0,82 \%$, pneumonia $0,71 \%$, sepsis $0,01 \%$, dekubitus $3,05 \%$, dan plebitis $4,25 \%{ }^{4}$

Tangan merupakan perantara yang paling sering menularkan patogen penyebab HCAI. ${ }^{3}$ Kepatuhan petugas kesehatan untuk melakukan praktik mencuci tangan masih rendah. Alasan yang sering dikemukakan adalah mencuci tangan dianggap menyita waktu dan cairan pencuci tangan dapat menyebabkan kulit menjadi kering dan teriritasi. Solusi terhadap hal ini adalah alcoholbased handrub. Cairan pencuci tangan berbasis alkohol membutuhkan waktu yang lebih singkat 
dalam pemakaian, sehingga lebih akseptabel. Selain itu cairan ini memiliki toleransi yang baik terhadap kulit atau tolerabel. ${ }^{2,3,5}$ World Health Organization (WHO) telah memformulasikan alcohol based handrub yang dapat diproduksi secara lokal. Terdapat dua jenis handrub formula WHO. Formula pertama memiliki komposisi yang terdiri dari ethanol $80 \%$, glycerol $1,45 \%$ dan hydrogen peroxide $0,125 \%$. Formula kedua terdiri dari isopropyl alcohol 75\%, glycerol 1,45\%, dan hydrogen peroxide $0,125 \%$. WHO merekomendasikan cairan pencuci tangan formula WHO sebagai cairan pencuci tangan alternatif jika cairan pencuci tangan komersial sulit didapatkan ataupun terlalu mahal. ${ }^{6}$

Mahasiswa Kepaniteraan Klinik Senior (KKS) merupakan salah satu petugas kesehatan yang bertugas di RSUD Arifin Achmad Provinsi Riau. Mahasiswa KKS bertugas di tiap-tiap bagian atau stase rumah sakit. Bagian Bedah, Obstetri dan Ginekologi, dan Penyakit Dalam merupakan tiga bagian dengan jumlah mahasiswa yang relatif lebih banyak dibanding bagian lainnya. Seringnya mereka berkontak dengan pasien menyebabkan mereka memiliki potensi menularkan patogen penyebab HCAI, sehingga mencuci tangan merupakan hal yang harus mereka lakukan secara rutin. Atas dasar inilah peneliti ingin melakukan penelitian mengenai tingkat akseptabilitas dan tolerabilitas cairan pencuci tangan formula WHO yang akan digunakan oleh Mahasiswa Kepaniteraan Klinik Senior (KKS) di Bagian Bedah, Obstetri dan Ginekologi, dan Penyakit Dalam RSUD Arifin Achmad Provinsi Riau.

Penelitian ini bertujuan untuk mengetahui tingkat akseptabilitas dan tolerabilitas cairan pencuci tangan formula WHO oleh Mahasiswa Kepaniteraan Klinik Senior di RSUD Arifin Achmad Provinsi Riau.

\section{METODE PENELITIAN}

Penelitian ini merupakan penelitian deskriptif untuk mengetahui tingkat akseptabilitas dan tolerabilitas cairan pencuci tangan formula WHO yang digunakan Mahasiswa Kepaniteraan Klinik Senior di RSUD Arifin Achmad Provinsi Riau. Subjek penelitian ini adalah mahasiswa/i KKS bagian Bedah, Obstetri dan Ginekologi, dan Penyakit Dalam RSUD Arifin Achmad Provinsi
Riau yang memenuhi kriteria inklusi dan kriteria eksklusi dengan jumlah 40 orang. Jumlah subjek penelitian ini sesuai dengan standar yang ditetapkan oleh WHO. Kriteria inklusi adalah mahasiswa KKS bagian Bedah, Obstetri dan Ginekologi, dan Penyakit Dalam yang bertugas di RSUD Arifin Achmad Provinsi Riau dan bersedia menjadi subjek penelitian. Kriteria ekslusi dalam penelitian ini adalah mahasiswa yang sedang tidak bertugas atau sedang menjalani masa cuti pada saat pengambilan data dan mahasiswa yang setelah dilakukan pemeriksaan oleh peneliti, memiliki kelainan kulit seperti dermatitis, mengalami rinitis, konjungtivitis, asma, dan intoleransi alkohol.

Sebelum melakukan penelitian, terlebih dahulu peneliti menyiapkan cairan pencuci tangan formula WHO. Selama proses pembuatannya, peneliti menggunakan alat pelindung diri seperti sarung tangan, masker, tutup kepala, dan baju lab. Cairan pencuci tangan formula WHO dibuat dengan memasukkan ethanol 96\% 8,333 $\mathrm{ml}$, hydrogen peroxide 3\% $417 \mathrm{ml}$, dan glycerol 98\%145 $\mathrm{ml}$ ke dalam botol atau tangki besar dengan menggunakan gelas ukur. Karena glycerol sangat lengket dengan dinding botol, maka sebelum dimasukkan glycerol harus dicampur dengan aquadest terlebih dahulu. Kemudian peneliti menambahkan aquadest ke dalam tangki hingga mencapai volume $1000 \mathrm{ml}$, dan terakhir menambahkan pewangi strawberry secukupnya. Tangki besar kemudian ditutup untuk mencegah terjadinya evaporasi. Semua bahan yang sudah ada di botol atau tangki besar dihomogenkan dengan cara dikocok. Cairan yang sudah dicampurkan tersebut, kemudian dimasukkan ke dalam botol plastik berukuran masing-masing 100 $\mathrm{ml}$ dan didiamkan selama 72 jam sebelum dilakukan uji akseptabilitas dan tolerabilitas. ${ }^{6}$

Sebelum responden menggunakan cairan pencuci tangan formula WHO, peneliti melakukan penilaian awal terhadap kondisi kulit responden, apakah terdapat kelainan kulit seperti dermatitis, kemudian rinitis, konjungtivitis, asma dan intoleransi alkohol. Kemudian cairan pencuci tangan formula WHO dibagikan pada responden untuk digunakan selama 3 hari. Setelah menggunakan cairan pencuci tangan formula WHO selama 3 hari, responden kemudian diminta untuk mengisi kuosioner bagian 1 tentang produk uji. Kuesioner ini adalah kuesioner untuk penilaian secara 
subjektif. Kuesioner yang digunakan adalah kuesioner yang telah ditetapkan oleh WHO. Selain penilaian subjektif yang dilakukan oleh responden, peneliti juga melakukan penilaian secara objektif terhadap kondisi tangan responden dengan menggunakan kuesioner yang telah ditetapkan oleh WHO. Penilaian secara objektif oleh peneliti menggunakan kuesioner bagian 2 . $^{7}$

\section{HASIL PENELITIAN}

Penelitian ini diikuti oleh 40 orang mahasiswa KKS dengan 12 responden dari Bagian Bedah, 12 responden dari Bagian Obstetri dan Ginekologi, dan 16 responden dari Bagian Penyakit Dalam. Penelitian dilaksanakan selama enam hari. Data gambaran tingkat akseptabilitas cairan pencuci tangan formula World Health Organization (WHO) yang digunakan oleh mahasiswa KKS bagian Bedah, Obstetri dan Ginekologi, dan Penyakit Dalam RSUD Arifin Achmad Provinsi Riau tercantum pada Gambar 1 dan 2 berikut ini :

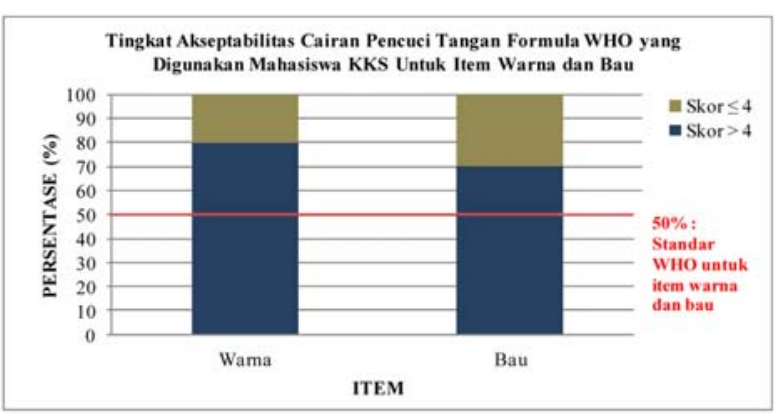

Gambar 1. Tingkat akseptabilitas cairan pencuci tangan formula WHO yang digunakan mahasiswa KKS untuk item warna dan bau

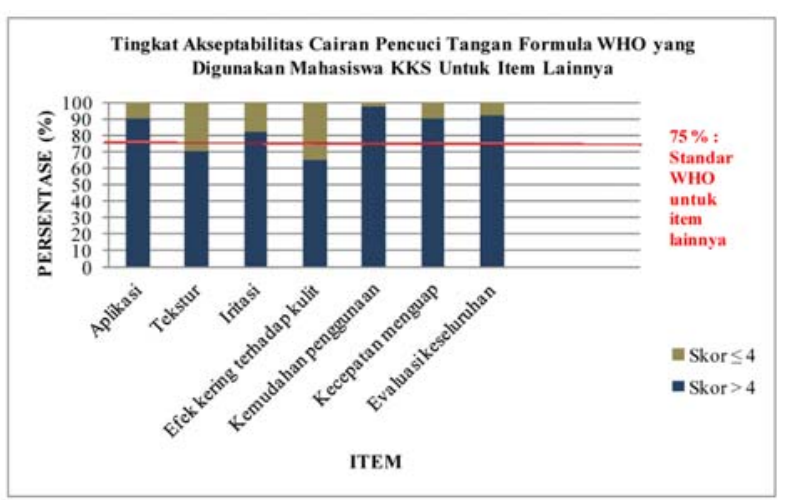

Gambar 2. Tingkat akseptabilitas cairan pencuci tangan formula WHO yang digunakan mahasiswa KKS untuk item selian warna dan bau
Gambar 1 dan 2 menggambarkan tingkat akseptabilitas cairan pencuci tangan formula WHO. Tingkat akseptabilitas dari masing-masing item secara berurutan yaitu, warna $80 \%$, bau $70 \%$, aplikasi $90 \%$, tekstur $70 \%$, efek mengiritasi $82,5 \%$, efek kering terhadap kulit 65\%, kemudahan penggunaan $97,5 \%$, kecepatan menguap $90 \%$, dan evaluasi keseluruhan 92,5\%.

Penilaian terhadap tingkat tolerabilitas cairan pencuci tangan formula WHO dilakukan secara subjektif dan objektif. Tingkat tolerabilitas yang dinilai secara subjektif dan objektif tercantum pada Gambar 3 dan 4 berikut ini.

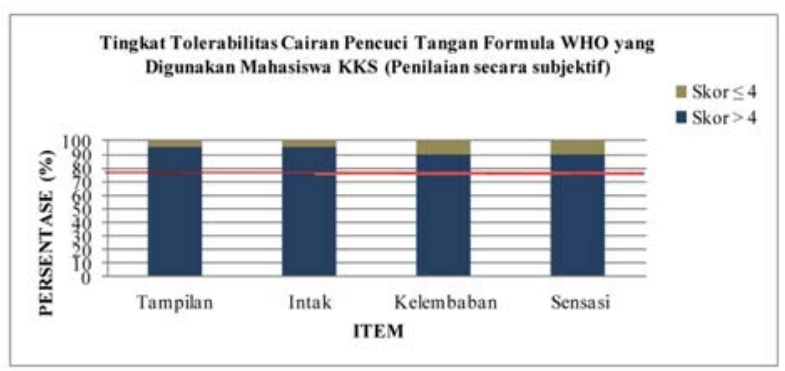

Gambar 3. Tingkat tolerabilitas cairan pencuci tangan formula WHO yang digunakan mahasiswa KKS (penilaian secara subjektif)

Gambar 3 menggambarkan penilaian secara subjektif tingkat tolerabilitas cairan pencuci tangan formula. Tingkat tolerabilitas dari masing-masing item secara berurutan yaitu, tampilan 95\%, intak 95\%, kelembaban 90\%, sensasi 90\%.

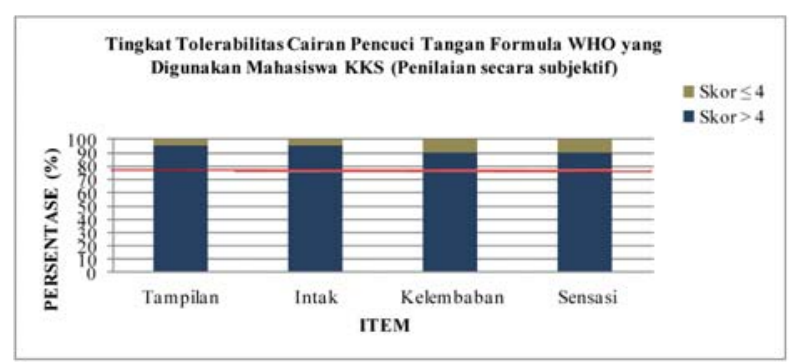

Gambar 4. Tingkat tolerabilitas cairan pencuci tangan formula WHO yang digunakan mahasiswa KKS (penilaian secara objektif)

Gambar 4 menggambarkan penilaian secara objektif tingkat tolerabilitas cairan pencuci tangan formula WHO. Tingkat tolerabilitas dari masingmasing item secara berurutan yaitu, kemerahan 
$100 \%$, retakan $100 \%$, fisura $100 \%$, skala penilaian kondisi kulit secara visual $100 \%$. Dari data ini didapatkan bahwa kondisi kulit responden setelah pemakaian cairan pencuci tangan formula WHO 100\% dalam kondisi yang baik.

Dari penelitian ini juga diketahui menurut 85\% responden, cairan pencuci tangan formula WHO dapat meningkatkan kepatuhan mereka dalam mencuci tangan. seperti pada gambar 5 berikut ini :

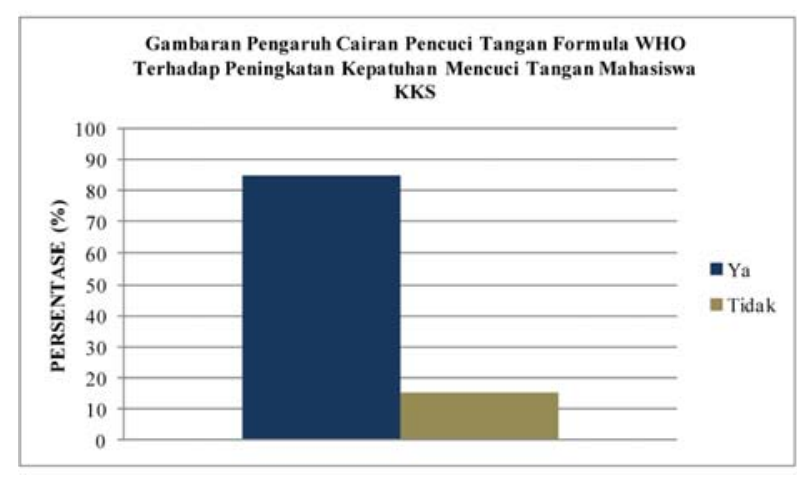

Gambar 5. Gambaran pengaruh pencuci tangan formula WHO terhadap peningkatan kepatuhan mencuci tangan mahasiswa KKS.

\section{PEMBAHASAN}

\section{Tingkat Akseptabilitas Cairan Pencuci Tangan Formula WHO}

Untuk item warna dan bau, cairan pencuci tangan formula WHO dikatakan memiliki akseptabilitas yang baik jika $\geq 50 \%$ responden memberi skor $>4$. Dinilai dari segi warna dan bau, cairan pencuci tangan formula WHO yang digunakan pada penelitian ini memiliki tingkat akseptabilitas yang baik. Untuk item warna, akseptabilitas yang didapatkan adalah sebesar $80 \%$. Cairan pencuci tangan yang diformulasikan oleh WHO bersifat bening atau tidak berwarna. Penambahan zat warna tidak direkomendasikan karena akan meningkatkan resiko terjadinya iritasi kulit. ${ }^{7}$ Dari penelitian ini dapat diketahui bahwa cairan pencuci tangan yang bening tetap memiliki tingkat akseptabilitas yang baik.

Dari segi bau atau aroma, pada penelitian ini peneliti menambahkan pewangi stroberi pada cairan pencuci tangan yang dibuat. Penambahan pewangi bertujuan untuk meminimalisir aroma khas dari ethanol. Pewangi dimasukkan dalam konsentrasi yang rendah dikarenakan penambahan pewangi dalam jumlah banyak akan meningkatkan resiko terjadinya alergi kulit. Selain itu, aroma yang terlalu pekat dapat menimbulkan masalah bagi mereka yang menderita alergi pada saluran pernapasan. ${ }^{6}$ Penambahan pewangi stroberi ke dalam cairan pencuci tangan menyebabkan cairan pencuci tangan formula WHO ini memiliki tingkat akseptabilitas yang baik dari segi bau, yaitu sebesar 70\%.

Untuk item lain selain warna dan bau, cairan pencuci tangan formula WHO dikatakan memiliki akseptabilitas yang baik jika $\geq 75 \%$ responden memberi skor $>4$. Berdasarkan penelitian yang dilakukan, didapatkan hasil cairan pencuci tangan formula WHO memiliki akseptabilitas yang baik dari segi aplikasi, sifat mengiritasi, kemudahan penggunaan, kecepatan menguap dan evaluasi keseluruhan namun kurang baik dari segi tekstur dan efek kering terhadap kulit. Dari segi aplikasi, sifat mengiritasi, kemudahan penggunaan, kecepatan menguap dan evaluasi keseluruhan didapatkan tingkat akseptabilitas masing-masing sebesar $90 \%$, 82,5\%, 97,5\%, 90\%, dan 92,5\%. Tingkat akseptabilitas yang baik pada item-item ini dikarenakan kandungan ethanol di dalamnya. Ethanol merupakan suatu cairan tidak berwarna yang bersifat mudah menguap. ${ }^{6}$ Sifat ini jugalah yang menyebabkan alcohol-based handrub formula WHO menjadi mudah digunakan, dimana dalam proses penggunaannya hanya membutuhkan waktu sekitar 20-30 detik dan dapat digunakan langsung di dekat pasien atau di titik tempat bekerja. ${ }^{8}$ Dari segi sifat mengiritasi, cairan pencuci tangan formula WHO memiliki tingkat akseptabilitas yang baik yaitu sebesar $82,5 \%$. Hal ini dikarenakan resiko terjadinya iritasi sudah diminimalisir dengan tidak diberikannya zat warna dan penambahan pewangi dalam konsentrasi rendah pada cairan pencuci tangan yang digunakan.

Dari segi efek kering terhadap kulit, tingkat akseptabilitas cairan pencuci tangan formula WHO tergolong kurang baik, yaitu sebesar 65\%. Efek ini dapat dikurangi dengan penambahan konsentrasi glycerol dengan catatan bahwa penambahan glycerol akan mengakibatkan tekstur alcohol-based handrub menjadi semakin lengket. Berdasarkan hasil penelitian ini, penambahan konsentrasi 
glycerol tidak dianjurkan, karena dari segi tekstur, alcohol-based handrub- pada penelitian ini sudah bertekstur agak lengket sehingga memiliki tingkat akseptabilitas yang kurang baik yaitu sebesar 70\%. Glycerol merupakan salah satu humektan yang sangat kental karena memiliki viskositas yang tinggi. Hal inilah yang diduga mengakibatkan tekstur lengket dan menimbulkan ketidaknyamanan dalam penggunaannya.Tekstur yang lengket ini dapat diminimalisir dengan mengurangi konsentrasi glycerol pada saat pembuatan alcohol-based handrub dengan catatan bahwa konsentrasi glycerol yang digunakan masih dalam rentang 1-3\%, karena glycerol dengan konsentrasi inilah yang berfungsi sebagai moisturizer yang berguna untuk meminimalisir sensasi kering pada kulit akibat kandungan ethanol. Namun berdasarkan hasil yang didapat pada penelitian ini, pengurangan konsentrasi glycerol juga tidak dianjurkan. Hal ini dikarenakan pengurangan glycerol akan semakin menambah sensasi kering pada kulit pemakainya.

Menurut WHO, penggunaan humektan lain sebagai alternatif glycerol dapat dipertimbangkan. ${ }^{7}$ Salah satu contoh humektan selain glycerol yaitu propylene glycol. Propylene glycol memiliki tekstur yang kurang lengket karena memiliki viskositas yang lebih rendah dibandingkan glycerol, namun memiliki harga yang relatif lebih tinggi dan lebih sulit didapatkan. Propylene glycol digunakan sebagai humektan pada konsentrasi $15 \%$. Kebanyakan emolien dapat digunakan secara aman dan efektif tanpa efek samping. Namun adanya sensasi panas, perih, kemerahan, ataupun iritasi kulit tetap mungkin terjadi dan hal ini harus diperhatikan, termasuk pada penggunaan propylene glycol.

World Health Organization menyatakan bahwa humektan atau emolien lain untuk menggantikan glycerol harus memenuhi beberapa persyaratan, yaitu harganya terjangkau, tersedia secara lokal, larut dalam air dan alkohol, bersifat non toksigenik, dan hipoalergenik. Glycerol direkomendasikan oleh WHO karena bersifat aman dan memiliki harga yang relatif murah. ${ }^{7}$ World Health Organization juga merekomendasikan penggunaan pelembab kulit atau lotion untuk mengurangi dermatitis kontak alergika maupun efek samping lain akibat penggunaan produk pencuci tangan. Lotion mengandung humektan, lemak, dan minyak yang dapat meningkatkan hidrasi kulit. ${ }^{2}$ Rendahnya tingkat akseptabilitas dari segi tekstur dan efek kering terhadap kulit ternyata tidak terlalu mempengaruhi peningkatan kepatuhan mencuci tangan mahasiswa KKS. Hal ini terlihat dari hasil penelitian yang mendapatkan bahwa 85\% responden menyatakan cairan pencuci tangan formula WHO yang digunakan dalam penelitian ini dapat meningkatkan kepatuhan mencuci tangan mereka.

\section{Tingkat Tolerabilitas Cairan Pencuci Tangan Formula WHO}

Tingkat tolerabilitas suatu cairan pencuci tangan dinyatakan baik jika seluruh item pada kuesioner Evaluasi Kondisi Kulit $\geq 75 \%$ responden memberi skor $>4$, dan pada kuesioner Skala Evaluasi Kondisi Kulit oleh Observer didapatkan skor $<2$ dengan persentase $\geq 75 \%$. Pada penelitian ini dapat diketahui bahwa cairan pencuci tangan formula WHO memiliki tingkat tolerabilitas yang baik. Hal ini tergambar dari persentase yang didapatkan untuk setiap item penilaian, baik untuk penilaian secara subjektif maupun penilaian secara objektif.Untuk tingkat tolerabilitas dinilai secara subjektif pada item tampilan dan intak, 38 orang (95\%) memberikan skor $>2$. dan 2 orang (5\%) memberikan skor $<2$. Dua orang responden ini memberikan skor 4 untuk semua item penilaian. Namun ketika dilihat secara objektif oleh peneliti, kulit kedua responden ini berada dalam kondisi yang baik.Untuk tingkat tolerabilitas dinilai secara objektif, didapatkan bahwa 100\% kulit responden berada dalam kondisi yang baik.

Keamanan penggunaan alcohol-based handrub didukung oleh data WHO yang menyatakan bahwa dermatitis kontak iritan maupun dermatitis kontak alergika jarang terjadi pada penggunaan alcohol-based handrub, terutama yang mengandung humektan ataupun emolien. Laporan dari salah satu rumah sakit besar diSwiss yang menggunakan alcohol-based handrub juga menyebutkan bahwa tidak didapatkan satupun reaksi alergi setelah lebih dari sepuluh tahun penggunaan di rumah sakit ini.

Keterbatasan pada penelitian ini terletak pada pengawasan terhadap para responden. Selama penggunaan produk uji, responden diharapkan untuk tidak menggunakan lotion atau produk hand care lainnya dengan tujuan untuk menghindarkan bias 
pada hasil penelitian. Hal ini tidak dapat diawasi oleh peneliti.

\section{KESIMPULAN}

Cairan pencuci tangan formula WHO yang digunakan mahasiswa KKS di RSUD Arifin Achmad Provinsi Riau memiliki tingkat akseptabilitas yang baik dinilai dari segi warna, bau, aplikasi, sifat mengiritasi, kemudahan penggunaan, kecepatan menguap, dan evaluasi keseluruhan namun kurang baik dari segi tekstur dan efek kering terhadap kulit. Pada tingkat tolerabilitas, cairan pencuci tangan formula WHO memiliki tingkat tolerabilitas yang baik.

\section{SARAN}

Cairan pencuci tangan formula WHO dapat direkomendasikan sebagai cairan pencuci tangan alternatif untuk digunakan para tenaga medis di pusat pelayanan kesehatan dan perlu dipertimbangkan penggunaan humektan selain glycerol untuk mendapatkan cairan pencuci tangan formula WHO dengan tekstur yang lebih baik dengan tetap mempertimbangkan masalah keamanan, harga, dan keterjangkauan humektan tersebut.

\section{DAFTAR PUSTAKA}

1. Program pencegahan dan pengendalian infeksi nosokomial merupakan unsur patient safety. Departemen Kesehatan Republik Indonesia, 2000. (diunduh 2011 November 2011). Tersedia dari: http://www.depkes.go.id/index.php/berita/ press-release/1710-program-pencegahan-danpengendalian-infeksi-nosokomial-merupakanunsur-patient-safety.html.
2. World Health Organization. WHO Guidelines on Hand Hygiene in Health Care, First Global Patient Safety Challenge Clean Care is Safer Care. Geneva: WHO; 2009

3. World Health Organization. Health CareAssociated Infection and Hand Hygiene Improvement - Slides For The Hand Hygiene Coordinator. Geneva: WHO; 2009.

4. Bina Program RSUD Arifin Achmad Pekanbaru. Daftar Infeksi Nosokomial Periode 2010-2011. Pekanbaru: RSUD; 2012.

5. World Health Organization. WHO Guidelines on Hand Hygiene in Health Care (Advanced Draft): A Summary. Geneva: WHO; 2005

6. World Health Organization. Guide to Local Production : WHO-Recommanded Handrubs Formulations. Geneva: WHO; 2009.

7. World Health Organization. Protocol for Evaluation and Comparision of Tolerability andAcceptibility of Alcohol-based Handrub in Use or Planned to be Introduced: Method 1. Geneva: WHO; 2009.

8. Pittet D. Improving Adherence to Hand Hygiene Practice: A Multidisciplinary Approach. Geneva: University of Geneva Hospitals; 2001 